\title{
PENYELESAIAN SENGKETA EKONOMI SYARI'AH DI LEMBAGA KEUANGAN SYARI'AH KABUPATEN BANYUMAS
}

\author{
Safitri Mukarromah ${ }^{1}$, Wage $^{2}$ \\ ${ }^{1}$ Fakultas Agama Islam Universitas Muhammadiyah Purwokerto, Email : \\ safitrimukarromah9@gmail.com \\ ${ }^{2}$ Fakultas Agama Islam Universitas Muhammadiyah Purwokerto, Email: \\ wagefsyah.2010@gmail.com
}

\begin{abstract}
ABSTRAK
Pesatnya perkembangan lembaga keuangan syari'ah berimplikasi pada kemungkinan timbulnya permasalahan atau sengketa antara pihak penyedia layanan dengan masyarakat yang dilayani. Mengantisipasi kemungkinan tersebut, diperlukan adanya lembaga penyelesaian sengketa yang mempunyai kredibilitas dan kompeten sesuai bidangnya, yaitu bidang ekonomi syariah. Lembaga penyelesaian sengketa yang kita kenal saat ini terdiri dari dua yaitu lembaga litigasi dan lembaga non litigasi. Penelitian ini bertujuan untuk mengetahui penyelesaian sengketa ekonomi syariah menurut peraturan perundang-undangan dan penyelesaian sengketa di lembaga keuangan syariah di wilayah banyumas. Data yang terkumpul akan dianalisis secara kualitatif dengan menggunakan metode deskriptif yaitu menguraikan gambaran dari data yang diperoleh dan menghubungkan satu sama lain untuk mendapatkan suatu kesimpulan umum. Hasil penelitian menunjukkan bahwa penyelesaian sengekta ekonomi syariah menurut peraturan perundang-undangan bisa diselesaikan secara litigasi melalui proses peradilan maupun secara non litigasi diluar proses peradilan. Menurut Undang-Undang Nomor 3 tahun 2006 Tentang Peradilan Agama menjelaskan bahwa sengketa ekonomi syariah menjadi kewenangan pengadilan agama. Sedangkan di lembaga keuangan syariah wilayah banyumas untuk pembiayaan bermasalah lebih banyak diselesaikan secara non litigasi atau dengan internal mereka sendiri dalam bentuk revitalisasi melalui restructuring, reschedulling, reconditioning dan bantuan manajemen.
\end{abstract}

Kata Kunci : Sengketa; Ekonomi; Syariah

\begin{abstract}
ABCTRACT
The rapid development of Shari'ah financial institutions has implications for the possibility of problems or disputes between the service providers and the people served. Anticipating this possibility, there is a need for dispute resolution institutions that have credibility and competency in accordance with their fields, namely the Islamic economy. The dispute resolution institution that we know today consists of two, namely litigation institutions and non-litigation institutions. This study aims to determine sharia economic dispute resolution according to legislation and dispute resolution in sharia financial institutions in the Banyumas region. The collected data will be analyzed qualitatively by using descriptive methods, namely describing a picture of the data obtained and connecting with each other to get a general conclusion. The results of the study show that the settlement of sharia economy in accordance with the laws and regulations can be resolved through litigation through the judicial process and non-litigation outside the judicial process. According to Law Number 3 of 2006 concerning Religious Courts, it is explained that sharia economic disputes are the authority of the religious court. Whereas in the banyumas area Islamic financial institutions for problem financing, more are resolved in non-litigation or with their own internal forms of revitalization through restructuring, rescheduling, reconditioning and management assistance.
\end{abstract}

Keywords: Dispute; Economics; Sharia. 


\section{PENDAHULUAN}

Perkembangan industri keuangan syari'ah secara umum terus mengalami peningkatan baik di industri keuangan bank syari'ah maupun non bank syari'ah. Berdasarkan dokumen OJK. Lampiran Surat No. S-309/KO.033/2017 tanggal 31 Mei 2017 bahwa pada industri perbankan syari'ah terdapat 12 Bank Umum Syari'ah, 22 bank umum yang memiliki Unit Usaha Syari'ah dan 165 Bank Pembiayaan Rakyat Syari'ah (BPRS). Sedangkan untuk industri keuangan non bank syari'ah mengalami perkembangan diantaranya terdapat 32 perusahaan IKNB syari'ah (full fledge) dan 91 perusahaan IKNB umum yang meiliki unit usaha syari'ah. Hal ini menunjukkan semakin tinggi kesadaran masyarakat terhadap pentingnya bermuamalah sesuai dengan ketentuan syari'ah.

Lembaga keuangan syari'ah di Indonesia mempunyai karakter tersendiri dibanding dengan negara-negara lain yaitu pada strategi pemasarannya yang bersifat market driven sebagai strategi untuk mendapat informasi tentang potensi pasar sebagi basis informasi bagi pemilihan, perumusan, dan penerapan strategi. Disamping itu juga dorongan bottom up dalam memenuhi kebutuhan masyarakat sehingga lebih bertumpu pada sektor riil juga menjadi keunggulan tersendiri. Berbeda dengan perkembangan keuangan syariah di Iran, Malaysia, dan Arab Saudi, dimana perkembangan keuangan syariahnya lebih bertumpu pada sektor keuangan, bukan sektor riil, dan peranan pemerintah sangat dominan. Selain dalam bentuk dukungan regulasi, penempatan dana pemerintah dan perusahaan milik negara pada lembaga keuangan syariah membuat total asetnya meningkat signifikan, terlebih ketika negara-negara tersebut menikmati windfall profit dari kenaikan harga minyak dan komoditas (Halim Alamsyah: 2012).

Perkembangan lembaga keuangan syari'ah juga diperkuat dengan adanya perundang-undangan sebagai payung hukum dalam pelaksanaannya. Undang-Undang Nomor 21 Tahun 2008 tentang Perbankan Syari'ah sebagai landasan legal formal yang khusus mengatur berbagai hal mengenai perbankan syari'ah di Indonesia. Undang-Undang No. 3 Tahun 2006 tentang perubahan atas Undang-Undang Nomor 7 Tahun 1989 tentang Peradilan Agama telah memberi amanat kepada lembaga peradilan Agama sebagai salah satu lembaga pelaksana kekuasaan kehakiman di Indonesia untuk menerima, memeriksa, mengadili serta menyelesaikan perkara-perkara tertentu termasuk perkara perbankan dan ekonomi Syariah yang terjadi di Indonesia.

Pesatnya perkembangan perbankan syari'ah dan lembaga keuangan syari'ah berimplikasi pada semakin besar kemungkinan timbulnya permasalahan atau sengketa antara pihak penyedia layanan dengan masyarakat yang dilayani. Mengantisipasi kemungkinan tersebut, diperlukan adanya lembaga penyelesaian sengketa yang mempunyai kredibilitas dan berkompeten sesuai bidangnya, yaitu bidang ekonomi syari'ah. lembaga penyelesaian sengketa yang kita kenal saat ini 
terdiri dari dua yaitu lembaga litigasi dan lembaga non litigasi. Dimana lembaga non litigasi dianggap lebih bisa mengakomodir kekurangan model litigasi dan memberikan jalan keluar lebih baik dengan proses yang dipandang menghasilkan kesepakatan win-win solution, menjamin kerahasiaan para pihak yang bersengketa dan mendapatkan keadilan, menghindari keterlambatan yang diakibatkan karena hal prosedural dan administratif, menyelesaikan masalah secara komprehensif dalam kebersamaan, dan tetap menjaga hubungan baik (Syahrizal Abbas, 2009).

Lembaga non litigasi saat ini sudah ada Badan Arbitrase Syari'ah Nasional (Basyarnas) merupakan lembaga Arbitrase yang berperan menyelesaikan sengketa antara pihak-pihak yang melakukan akad dalam ekonomi syari'ah, di luar jalur pengadilan, untuk mencapai penyelesaian terbaik ketika upaya musyawarah tidak menghasilkan mufakat. Putusan Basyarnas bersifat final dan mengikat (binding). Untuk melakukan eksekusi atas putusan tersebut, penetapan eksekusinya diberikan oleh Pengadilan Negeri setempat. sebagai pengganti dari Badan Arbitrase Muamalat Indonesia(Bamui) Bamui adalah cikal bakal Basyarnas. Lembaga ini didirikan berdasarkan SK MUI No Kep-392/MUI/V/1992, bersamaan dengan pendirian Bank Muamalat Indoensia (BMI) tahun 1992. Tujuannya untuk menangani sengketa antara nasabah dan bank syari'ah pertama tersebut. Pada tahun 2003, beberapa bank atau Unit Usaha Syari'ah (UUS) lahir sehingga Bamui dirubah menjadi Basyarnas. Perubahan tersebut berdasarkan SK MUI No Kep-09/MUI XII/2003 tertanggal 24 Desember 2003, dan beberapa Badan Arbitrase Syari'ah Daerah (Basyarda). Sedangkan untuk lembaga litigasi dilaksanakan melalui lembaga peradilan agama sesuai dengan kewenangannya seperti yang sudah dijelaskan tersebut di atas. Untuk perkara ekonomi syari'ah yang masuk jalur litigasi masih belum terlalu banyak. Berdasarkan hasil penelitian yang dilakukan Safitri Mukarromah pada tahun 2016, didapatkan data bahwa di Pengadilan Agama se-eks Karesidenan Banyumas terdapat 32 perkara sengketa ekonomi syari'ah terdiri dari; Purwokerto sebanyak 4 perkara, Banjarnegara sebanyak 1 perkara, Cilacap sebanyak 5 perkara dan Purbalingga sebanyak 23 perkara (Safitri Mukarromah, Thesis 2016). Beberapa Perbankan syari'ah dan lembaga keuangan syari'ah wilayah Purwokerto dalam menyelesaikan perkara ekonomi syari'ah (wanprestasi) masih menggunakan jalur non litigasi. Artinya mereka masih menyelesaikan secara internal antara pihak perbankan dengan nasabah, namun apabila tidak didapat kesepakatan antara kedua belah pihak, barulah perkara tersebut diajukan ke Pengadilan Agama.

Ekonomi Syari'ah adalah sistem ekonomi yang berbasis pada Al-Qur'an dan sunah, dimana tujuan dari ekonomi syari'ah sendiri adalah mensejahterakan masyarakat, bila masyarakat belum sejahtera maka tujuan ekonomi syari'ah belum terlaksana. Sedangkan Konflik atau sengketa merupakan sesuatu yang menyebabkan perbedaan pendapat antara dua pihak atau lebih yang berselisih 
perkara dalam pengadilan (Sudarsono,2002: 433). Konflik atau sengketa juga bisa terjadi karena adanya perbedaan persepsi yang merupakan penggambaran tentang lingkungan baik fisik maupun sosial yang dilakukan secara sadar yang didasari pengetahuan yang dimiliki seseorang. Sebuah konflik akan berlanjut menjadi sebuah sengketa apabila pihak yang merasa dirugikan menyatakan rasa ketidakpuasannya yang menyebabkan kerugian pada dirinya yang disampaikan secara langsung maupun melalui pihak lain.

Nur jannah dalam penelitiannya berjudul Strategi Penyelamatan Pembiayaan Bermasalah pada Pembiayaan Murabahah di Bank Syariah Mandiri Cabang Purwokerto menunjukkan bahwa strategi yang digunakan ada dua, yakni stay strategy dan exit strategy. Stay strategi digunakan apabila pihak bank masih ingin menjalin hubungan bisnis dengan nasabah. Strategi ini dilakukan melalui Upaya restrukturisasi (seperti rescheduling, reconditioning, dan restructuring). Penelitian Illy Yanti dan habriyanto dengan judul Penyelesaian Sengketa Ekonomi Syariah di Lembaga Keuangan Syariah Kota Jambi menunjukkan bahwa sengketa ekonomi pada umumnya terjadi pada kasus wanprestasi dimana nasabah tidak mampu memenuhi kewajibannya pada Bank Syariah Mandiri Cabang Jambi secara umum diselesaikan melalui mediasi. Sedang pada Asuransi Takaful klaim asuransi menjadi kasus yang paling banyak terjadi dengan penyelesaiannya menggunakan jalur mediasi. Prosedur penyelesaian sengketa ekonomi Islam pada pada kedua lembaga dilakukan dengan jalur non litigasi terlebih dahulu, jika jalur non litigasi tidak berhasil maka penyelesaian sengketa tersebut baru dilakukan dengan jalur litigasi (peradilan).

Berdasarkan hal tersebut di atas, maka dapat dirumuskan permasalahan yaitu bagaimana penyelesaian sengketa ekonomi syari'ah dalam peraturan perundangan-undangan dan bagaimana penyelesaian sengketa ekonomi syari'ah di lembaga keuangan syari'ah kabupaten Banyumas? Penelitian ini bertujuan untuk mengetahui Penyelesaian sengketa ekonomi syari'ah dalam konsep peraturan Perundang-undangan dan penyelesaian sengketa ekonomi syari'ah di lembaga keuangan syari'ah kabupaten Banyumas.

\section{METODE PENELITIAN}

Penelitian yang dilakukan merupakan jenis penelitian lapangan (field research) yakni penelitian yang langsung berhubungan dengan obyek yang diteliti (Hadi Sutrisni, 2001:32). Pada penelitian ini diarahkan untuk mengungkap penyelsaian sengketa ekonomi syari'ah secara peraturan perundang-undangan dan penyelesaian di lembaga keuangan syari'ah. Dalam penelitian ini sumber data yang digunakan adalah data primer dan sekunder. Data primer adalah data yang digali dari data utama. Data sekunder adalah data yang diperoleh melalui hasil pengolahan pihak kedua dari penelitian lapangan, baik kualitattif maupun kuantitatif. Sumber data primer adalah lembaga keuangan syari'ah yang ada di kabupaten Banyumas. 
sedangkan sumber data sekunder adalah buku, artikel, jurnal, majalah atau tulisan lain yang menunjang penelitian yaitu yang membahas tentang sengketa ekonomi syari'ah. Data yang terkumpul akan dianalisis secara kualitatif dengan menggunakan metode deskriptif. Analisis data yang diperoleh dilakukan dengan cara analisis kualitatif yaitu analisis kualitatif yang dipergunakan untuk aspek-aspek normatif (yuridis) melalui metode yang bersifat deskriptif analisis, yaitu menguraikan gambaran dari data yang diperoleh dan menghubungakan satu sama lain untuk mendapatkan suatu kesimpulan umum. Dari hasil analisis tersebut dapat diketahui serta diperoleh kesimpulan induktif, yaitu cara berpikir dalam mengambil kesimpulan secara umum yang didasarkan atas fakta-fakta yang bersifat khusus (Soerjono Soekanto, 1986:112).

Metode ini digunakan untuk mendeskripsikan dari aspek ekonomi syari'ah yaitu dengan menjabarkan data yang telah diperoleh berdasarkan peraturan perundangan maupun hukum Islam yang relevan dengan pokok pembahasan. Sedangkan untuk menganalisis data yang diperoleh dipergunakan metode induktif, yakni berusaha mencari aturan-aturan, nilai-nilai maupun norma-norma hukum yang terdapat dalam pustaka dan dirumuskan sebagai suatu kaidah hukum tertentu yang bisa diberlakukan untuk menyelesaikan kasus sengketa ekonomi syari'ah di lembaga keungan syari'ah.

\section{HASIL DAN PEMBAHASAN}

Penerapan sistem ekonomi syari'ah di Indonesia pada gilirannya menuntut adanya perubahan diberbagai bidang, terutama berkenaan dengan peraturan perundang-undangan yang mengatur dasar pokok ekonomi dan keuangan. Kehadiran sistem perbankan syariah di Indoensia juga berimplikasi para peraturan perundang-undangan yang mengatur institusi lain, misalnya lembaga peradilan. Pasca amandemen Undang-Undang Nomor 7 Tahun 1989 menjadi Undang-Undang Nomor 3 Tahun 2006 tentang Peradilan Agama telah memberikan perubahan yang sangat signifikan terutama terkait dengan kompetensi absolut peradilan agama karena sebelumnya peradilan agama berdasarkan Undang-Undang Nomor 7 tahun 1989 hanya berwenang menyelesaikan sengketa perkawinan, waris, wasiat, hibah, wakaf, zakat, infaq dan shadaqah. Tetapi dengan lahirnya Undang-Undnag Nomor 3 Tahun 2006 ada perubahan yang mendasar yaitu penambahan kewenangan menyelesaikan sengketa ekonomi syari'ah sebagaimana dalam ketentuan pasal 49 huruf i "Ketentuan pasal 49 diubah sehingga berbunyi sebagai berikut: Pengadilan Agama bertugas dan berwenang memeriksa, memutus, dan menyelesaikan perkara ditingkat pertama antara orang-orang yang beragama Islam dibidang; perkawinan, waris, wasiat, hibah, wakaf, zakat, infaq, shadaqah, dan ekonomi syari'ah" (Undang-Undang Nomor 3 Tahun 2006).

Penjelasan Pasal 49 huruf i Undang-Undang Nomor 3 Tahun 2006 dinyatakan bahwa yang dimaksud ekonomi syariah adalah perbuatan atau kegiatan usaha yang 
dilaksanakan menurut prinsip syariah meliputi: bank syariah, lembaga keuangan mikro syariah, asuransi syariah, reasuransi syariah, reksadana syariah, obligasi syariah dan surat berjangka menengah syariah, sekuritas syariah, pembiayaan syariah, pegadaian syariah, dana pensiun lembaga keuangan syariah, dan bisnis syariah. Cakupan ekonomi syariah sangat luas, dalam hal ini tercakup lingkup lembaga keuangan bank maupun lembaga keuangan non bank yang mendasarkan pengelolaan operasionalnya menggunakan prinsip syariah. Terkait dengan penyelesaian sengketa ekonomi syariah di lembaga keuangan bank maupun lembaga keuangan non bank dalam cakupan sistem hukum ekonomi syariah di Indonesia ada beberapa dasar hukumnya yaitu:

1. Undang-Undang Nomor 30 Tahun 1999 tentang Arbitrase dan Alternatif Penyelesaian Sengketa, mengatur tentang penyelesaian sengketa atau beda pendapat di luar pengadilan melalui prosedur yang disepakati yakni melalui konsultasi, mediasi, negosiasi, konsiliasi, dan penilaian ahli;

2. Perautan Bank Indonesia No.8/5/PBI/2006 tentang Mediasi Perbankan, tanggal 30 Januari 2006, sebagai dasar terbentuknya Lembaga Mediasi Perbankan Independen (LMPI) oleh Asosiasi Perbankan. Pada Pasal 4 ayat (1), (2) dan ayat (3) Peraturan Bank Indonesia No. 9/19/PBI/2007 tentang Pelaksanaan Prinsip Syariah Dalam Kegiatan Penghimpunan Dana dan Penyaluran Dana Serta Pelayanan Jasa Bank Syariah, dijelaskan bahwa solusi Penyelesaian Sengketa antara Bank dengan Nasabah pada intinya bahwa dalam hal salah satu pihak tidak memenuhi kewajiban sebagaimana tertuang dalam akad antara Bank dengan Nasabah, atau jika terjadi sengketa antara Bank dengan Nasabah penyelesaian dilakukan melalui musyawarah, bila tidak bisa diselesaikan melalui musyawarah, maka diselesaikan melalui mediasi, dan jika tidak bisa diselesaikan melalui mediasi, maka penyelesaian sengketa dapat dilakukan melalui arbitrase syariah atau melalui lembaga peradilan berdasarkan perundang-undangan yang berlaku;

3. Peraturan Bank Indonesia No. 9/19/PBI/2007 Tentang Pelaksanaan Prinsip Syariah Dalam Kegiatan Penghimpunan Dana dan Penyaluran Dana Serta Pelayanan Jasa Bank Syariah, tanggal 17 Desember 2007;

4. Undang-Undang Nomor 3 Tahun 2006 perubahan Pertama UU No.7 Tahun 1989 Tentang Peradilan Agama, Perubahan kedua dengan Undang-Undang Nomor 50 Tahun 2009;

5. Undang-Undang Nomor 21 Tahun 2008 tentang Perbankan Syariah Pasal 55 menyebutkan: (1) penyelesaian sengketa perbankan syariah dilakukan oleh Pengadilan dalam lingkup peradilan agama; (2) Dalam hal para pihak telah memperjanjikan penyelesaian sengketa selain sebagaimana dimaksud pada ayat 1 penyelesaian sengketa dilakukan sesuai dengan isi akad; (3) Penyelesaian 
sebagaimana dimaksud pada ayat 2 tidak boleh bertentangan dengan prinsip syariah;

6. Putusan Mahkamah Konstitusi (MK) No.93/PUU-X/2012 tanggal 28 Maret 2013;

7. Peraturan Mahkamah Agung Republik Inonesia Nomor 1 Tahun 2016 Tentang Prosedur Mediasi di Pengadilan (Trubus Wahyudi, Makalah disampaikan dalam "Seminar Nasional Penyelesaian Sengketa Perbankan Syariah" yang diselenggarakan oleh Fakultas Hukum Universitas Negeri Semarang (UNNES) pada tanggal 12 Oktober 2016).

Berdasarkan aturan normatif tersebut diatas maka penyelesaian sengketa ekonomi syariah di lembaga keuangan syariah ada dua proses penyelesaian, yakni:

1. Proses Litigasi

Litigasi merupakan proses penyelesaian sengketa di pengadilan, dimana semua pihak yang bersengketa saling berhadapan satu sama lain untuk mempertahankan hak-haknya dimuka pengadilan. hasil akhir dari suatu penyelesaian sengketa melalui litigasi adalah putusan yang menyatakan win-lose solution (Nurnaningsih Amriani, 2012:35). Proses penyelesaian secara litigasi dilaksanakan dengan proses beracara di pengadilan dimana kewenangan untuk mengatur dan memutuskannya dilaksanakan oleh hakim.

Berdasarkan penjelasan Pasal 49 huruf (i) Undang-Undang Nomor 3 Tahun 2006 tentang Peradilan Aagama, maka seluruh nasabah lembaga keuangan dan lembaga pembiayaan syariah dan / atau bank-bank konvensional yang membuka sektor usaha syariah maka dengan sendirinya terikat dengan ketentuan ekonomi syariah, baik dalam hal pelaksanaan akadnya maupun dalam hal penyelesaian perselisihannya. Dalam hal penyelesaian perkara perdata yang diajukan ke Pengadilan Agama, pengadilan tersebut tidak mempunyai pilihan selain harus menyelesaikannya. Pengadilan tidak boleh menolak mengadili perkara yang diajukan kepadanya dengan alasan hukum tidak ada atau tidak jelas.

Terhadap perkara-perkara yang diajukan ke pengadilan tersebut, sesuai dengan aturan perundangan maka penyelesaiannya hanya ada dua kemungkinan, yaitu: pertama, diselesaikan melalui perdamaian atau apabila upaya damai tidak berhasil maka cara kedua, dengan diselesaikan melalui proses persidangan seperti biasa sesuai dengan ketentuan hukum acara perdata yang berlaku. Kedua cara inilah yang harus ditempuh Pengadilan Agama dalam menyelesaikan perkara-perkara dibidang ekonomi syariah umumnya dan bidang perbankan syariah khususnya yang diajukan kepadanya (Cik Basir, 2009:127). Khusus mengenai sengketa ekonomi syariah yang menjadi kewenangan absolut 
pengadilan agama meliputi: a) Sengketa di bidang ekonomi syariah antara lembaga keuangan dan lembaga pembiayaan syariah dengan nasabahnya; b) Sengketa di bidang ekonomi syariah antara sesama lembaga keuangan dan lembaga pembiayaan syariah; dan c) Sengketa di bidang ekonomi syariah antara orang-orang yang beragama Islam, yang aman akad perjanjiannya disebutkan dengan tegas bahwa kegiatan usaha yang dilakukan adalah berdasarkan prinsip-prinsip syariah (Ahmad Mujahidin, 2010:19).

Ketentuan peraturan perundang-undangan yang berlaku di lingkungan Peradilan Agama dan menjadi landasan dalam menyelesaikan sengketa ekonomi syari'ah adalah terdiri dari:

a. Sumber hukum formil

Hukum acara yang berlaku di lingkungan Peradilan Agama untuk mengadili sengketa ekonomi syari'ah adalah hukum acara yang berlaku dan dipergunakan pada lingkungan peradilan umum, yaitu: HIR (Het Herziene Inlandsche Reglement), R.Bg (Rechts Reglement Buitengewesten), termasuk juga ketentuan yang diatur dalam Rv (Reglement of de Rechtsvordering), KUH Perdata (BW), Undang-Undang Nomor 4 Tahun 2004 Tentang Kekuasaan Kehakiman, Undang-Undang Nomor 5 Tahun 2004 Tentang Mahkamah Agung dan Undnag-Undang Nomor 8 tahun 2004 Tentang Perdailan Umum dan Undang-Undang Nomor 3 Thaun 2006 Tentang Peradilan Agama serta beberapa peraturan lain yang berkenaan dengan perkara ekonomi syariah (Ahamad Mujahidin, 2010: 20).

b. Sumber Hukum Materiil

Sumber-sumber hukum yang terpenting untuk dijadikan dasar dalam mengadili perkara-perkara ekonomi syariah di lingkungan pengadilan agama adala Al-Qur'an dan Sunnah sebagai sumber utama dan sumber hukum lain yaitu:

1) Peraturan Perundang-undangan yang berkaitan dengan ekonomi syariah maupun Bank Indonesia. Ada 14 aturan perbankan dan 35 Undang-Undang yang bersentuhan dengan Undang-Undang Nomor 3 Tahun 2006 jo Undang-Undang Nomor 50 Tahun 2009 dan PERMA Nomor 3 Tahun 2008 Tentang Kompilasi Hukum Ekonomi Syariah (KHES);

2) Fatwa-fatwa dewan Syari'ah Nasional. Ada sekitar 120 fatwa DSN MUI tentang kegiatan ekonomi syariah;

3) Kitab-kitab fiqh. sebagian besar kitab fiqih yang mu'tabar berisi berbagai masalah muamalah yang dapat dijadikan acuan dalam menyelesaikan masalah ekonomi syari'ah;

4) Adat kebiasaan; 
5) Yurisprudensi (Ahmad Mujahidin, 2010: 23-30).

Prosedur dalam jalur litigasi ini sifatnya lebih formal dan teknis, menghasilkan kesepakatan yang bersifat menang kalah, cenderung menimbulkan masalah baru, lambat dalam penyelesainnya, membutuhkan biaya yang mahal, tidak responsif dan bersengketa. Kondisi ini menyebabkan masyarakat mencari alternatif lain yaitu penyelsaian sengketa di luar proses peradilan formal.

2. Proses Non Litigasi

Penyelesaian sengketa melalui non litigasi dikenal dengan istilah Alternative Dispute Resolution (ADR) adalah penyelesaian sengketa alternatif. Alternative Dispute Resolution merupakan suatu pranata penyelesaian sengketa diluar pengadilan berdasarkan kesepakatan para pihak dengan mengesampingkan penyelesain sengketa secara litigasi di pengadilan. Pasal 1 butir 10 Undang-Undang Nomor 30 Tahun 1999 mengartikan bahwa Alernative Dispute Resolution (ADR) adalah lembaga penyelesaian sengketa atau beda pendapat melalui prosedur yang disepakati para pihak, yakni penyelesaian di luar pengadilan dengan cara konsultasi, negosiasi, mediasi, konsiliasi, atau penilaian ahli (Undang-Undang No.30 Tahun 1999). Philip D. Bostwick menyatakan bahwa ADR merupakan serangkaian praktek dan teknik-teknik hukum yang ditujukan untuk:

1) Memungkinkan sengketa-sengketa hukum diselesaikan diluar pengadilan untuk keuntungan atau kebaikan para pihak yang bersengketa

2) Mengurangi biaya atau keterlambatan kalau sengketa tersebut diselesaikan melalui litigasi konvensional

3) Mencegah agar sengketa-sengketa hukum tidak dibawa ke pengadilan (Dadan Muttaqien, 2014:19).

Di Indonesia perkembangan Alernative Dispute Resolution (ADR) yang paling menonjol adalah Arbitrase. Arbitrase merupakan suatu lembaga alternatif yang diselenggarakan oleh dan berdasarkan kehendak serta itikad baik dari pihak yang berselisih agar perselisihan mereka tersebut diselesaikan oleh hakim yang mereka tunjuk dan angkat sendiri, dengan pengertian bahwa putusan yang diambil oleh hakim tersebut merupakan putusan yang bersifat final dan mengikat kedua belah pihak untuk melaksanakannya (Dadan Muttaqien, 2014:19).

Dua badan Arbitrase di Indonesia yaitu BANI (badan Arbitrase Nasional Indonesia) dan BAMUI (Badan Arbitrase Muamalat Indonesia). BANI adalah lembaga arbitrase yang bertujuan memberikan penyelesaian yang adil dan cepat dalam sengketa-sengketa perdata bersifat nasional maupun internasional. BANI adalah jenis arbitrase yang melembaga, dimana bentuk arbitrase semacam ini 
akan tetap ada walaupun sengketa yang telah diputus telah selesai atau telah ada sebelum sengketa ini timbul. Dimana keberadaannya hanya untuk melayani dan memutuskan kasus perselisihan tertentu dan setelah sengketa telah diputus, keberadaan dan fungsi Arbitrase ini lenyap dan berakhir begitu saja (Dadan Muttaqien, 2014:19).

BAMUI didirikan dalam rangka menyelesaikan perkara-perkara perdata yang timbul antara lembaga-lembaga keuangan syariah baik bank maupun lembaga keuangan syariah lainnya yaitu persengketaan yang timbul antara lembaga keuangan syariah dan atau antara nasabah atau anggota dengan lembaga keuangan. Pada perkembangannya BAMUI diubah menjadi BASYARNAS (Badan Arbitrase Syari'ah Nasional). Basyarnas berdiri secara otonom dan independen sebagai salah satu instrumen hukum yang menyelesaikan perselisihan para pihak, baik yang datang dari dalam lingkungan bank syariah, asuransi syariah, maupun pihak lain yang memerlukannya. Bahkan dari kalangan non muslim pun dapat memanfaatkan Basyarnas selama yang bersangkutan mempercayai kredibilitasnya dalam menyelesaikan sengketa (Dadan Muttaqien, 2014:19).

Alernative Dispute Resolution (ADR) saat ini telah menjadi pilihan masyarakat dalam menyelesaikan sengketa dikarenakan kekurangpuasan terhadap proses peradilan yang memakan waktu relatif lama, mahal, dan prosesnnya belum final karena masih bisa dilakukan upaya hukum serta bisa menimbulkan perasaan bermusuhan diantara para pihak. Pada lembaga keuangan syariah baik bank maupun non bank terdapat beberapa bentuk sengketa ekonomi syariah secara garis besar terbagi menjadi tiga, yakni: Pertama, sengketa di bidang ekonomi syariah antara lembaga keuangan dan lembaga pembiayaan syariah dengan nasabahnya; Kedua, sengketa di bidang ekonomi syariah antara lembaga keuangan dan lembaga pembiayaan syariah; Ketiga, sengketa di bidang ekonomi syariah antara orang-orang yang beragama Islam, yang mana akad perjanjiannya disebutkan dengan tegas bahwa kegiatan usaha yang dilakukan adalah berdasarkan prinsip-prinsip syariah (Ahmad Mujahidin, 2010:43).

Menurut Ahmad Mujahidin sengketa ekonomi syari'ah juga bisa dalam bentuk perkara Permohonan Pernyataan Pailit (PPP) dan juga bisa berupa Penundaan Kewajiban Pembayaran Utang (PKPU) di bidang ekonomi syari'ah, di samping itu juga perkara derivatif kepailitan (perkara tidak murni sebagai perkara kepailitan) (Ahmad Mujahidin, 2010:43). Sedangkan dalam hal pembiayaan bermasalah pada lembaga keuangan syariah, ada beberapa faktor yang menyebabkan terjadi kemacetan dalam pembiayaan tersebut. Analisa terhadap sebab-sebab kemacetan pembiayaan dapat dilakukan pada aspek internal dan eksternal berikut: 
1) Aspek internal terdiri dari: Peminjam kurang cakap dalam usaha tersebut; Manajemen tidak baik atau kurang rapih; Laporan keuangan tidak lengkap; Penggunaan dana yang tidak sesuai dengan perencanaan; Perencanaan yang kurang matang; Dana yang diberikan tidak cukup menjalankan usaha tersebut.

2) Aspek eksternal terdiri dari: Aspek Pasar kurang mendukung; Kemampuan daya beli masyarakat kurang; Kebijakan pemerintah; Pengaruh lain di luar usaha; Kenakalan peminjam (Muhammad, 2002: 168-169).

Penanganan pada pembiayaan bermasalah merupakan bagian yang tidak dapat dihindari dalam proses penyaluran pembiayaan. Karena setiap realisasi pembiayaan yang dilakukan pasti memiliki potensi pembiayaan bermasalah. Sehingga jika ditemukan gejala dini pembiayaan bermasalah, maka harus segera diambil langkah penanganan yang tepat sebelum masalah menjadi semakin besar.

Berdasarkan hasil wawancara dengan pihak BMT Dana Mentari, ada beberapa faktor yang harus diperhatikan oleh Account Officer yang dapat mempengaruhi kualitas pembiayaan antara lain: karakter mitra, analisis keuangan mitra, struktur modal, kemampuan produksi, siklus usaha, jaminan, pemantauan-pembinaan. Penanganan terhadap pembiayaan bermasalah dilakukan dengan cara preventif dan kuratif. Penanganan secara preventif yaitu: dengan cara pemahaman dan pelaksanaan proses pembiayaan yang benar, menyangkut internal dan eksternal; pemantauan dan pembinaan pembiayaan (on site dan on desk monitoring); serta pemahaman faktor yang menjadi penyebab dan gejala dini pembiayaan bermasalah. Sedangkan penanganan secara kuratif adalah dengan cara Account Officer melakukan analisis-evaluasi ulang mengenai aspek manajemen, pemasaran, produksi, keuangan, yuridis, agunan (Wawancara dengan Ibu Indi, tanggal 28 Mei 2018). Adapun penyelesaian sengketa terkait pembiayaan bermasalah di Bank Muamalat hampir sama dengan di BMT Dana Mentari yakni dilakukan dalam bentuk:

1) Revitalisasi yang dilakukan dengan cara penataan kembali (restructuring), penjadwalan kembali (rescheduling), persyaratan kembali (reconditioning) dan bantuan manajemen. Penataan kembali (Restructuring) dapat dilakukan dengan penambahan dana (suplesi) dimana mitra boleh mengambil kembali sisa baki debet selama masih dalam jangka waktu pembiayaan yang disetujui dalam akad dan juga bisa dengan novasi. Kemudian dilakukan penjadwalan kembali (Rescheduling) dengan mengubah jangka waktu pembiayaan, jadwal pembayaran dan jumlah angsuran. Hal ini dilakukan apabila terjadi ketidakcocokan jadwal angsuran yang dibuat account officer dengan kemampuan dan kondisi mitra. pemecahannya adalah dengan mengevaluasi dan menganalisis kembali seluruh kemampuan usaha mitra sehingga cocok 
dan tepat dengan jadwal yang baru. Lembaga keuangan tidak perlu meneliti ulang tentang jaminan dan segala bentuk perjanjian yang ada. Selanjutnya dilakukan persyaratan kembali (Reconditioning), dimana lembaga keuangan melakukan tindakan ini terhadap mitra apabila terdapat: perubahan kepemilikan usaha; perubahan jaminan apakah dalam hal bentuk, harga, maupun status; perubahan pengurus; perubahan nama dan status perusahaan. Keempat hal tersebut akan menyebabkan perubahan penanggung jawab pembiayaan dan perubahan status yuridis perusahaan yang mungkin tidak tepat lagi dengan menggunakan perjanjian semula. Bantuan manajemen dilakukan apabila dari hasil evaluasi ulang aspek manajemen yang menjadi faktor penyebab terjaidnya pembiayaan bermasalah, maka koperasi akan melakukan asistensi atau bantuan manajemen terhadap usaha mitra.

2) Collection agent yaitu apabila pejabaat koperasi dalam melakukan pengihan pembiayaan bermasalah hasilnya tidak cukup efektif, maka boleh menggunakan jasa pihak ketiga untuk melakukan penagihan, dengan syarat bahwa personal yang bersangkutan harus capable, credible, amanah dan memahami prinsip-prinsip syariah dalam menagih.

3) Penyelesaian melalui jaminan (eksekusi) yang dilakukan dengan cara: non litigasi melalui likuidasi usaha dan parate eksekusi dan melalui write off sementara

4) Write Off final dilakukan dengan penghapusan buku dan penghapusan tagihan. Penghapusan buku yaitu penghapusan seluruh pembiayaan mitra yang sudah tergolong macet, akan tetapi masih akan tetap ditagih. Sedangkan penghapusan tagihan yaitu penghapusbukuan dan penghapustagihan seluruh pembiayaan mitra yang sudah nyata-nyata macet.

Penghapus bukuan hanya boleh dilakukan terhadap mitra yang pembiayaan sudah tergolong macet akan tetapi berdasar analisis koperasi secara material masih ada sumber walau sangat terbatas jumlahnya untuk membayar. Pengapustagihan hanyalah dilakukan terhadap mitra yang pembiayaannya sudah macet dan berdasarkan analisis ekonomi yang dilakukan pihak koperasi, mitra yang bersangkutan nyata-nyata tidak mempunyai sumber dan kemampuan untuk membayar.

Sumber pengahapusan adalah dana penyisihan penghapusan Aktiva Produktif wajib dibentuk (PPAP WD). Perolehan pembayaran kembali dari mitra yang dihapusbukuan akan dimasukkan ke dalam rekening PPAP. Sumber penghapustagihan adalah dana zakat yang dikelola oleh Baitul Maal. Untuk setiap rencana penghapusan pembiayaan, baik yang berupa penghapusanbukuan dan terlebih penghapustagihan haruslah diajukan oleh manajer KSPS Dana Mentari Muhammadiyah Purwokerto kepada pengurus. 
Proses penyelesaian sengketa terkait pembiayaan bermasalah dilakukan dengan menganalisis atau mengkaji ulang penyebab pembiayaan bermasalah, penentuan alternatif solusi, pelaksanaan penangana/penyelesaian, monitoring dan evaluasi. Pembenahan pembiayaan secara preventif ini oleh Account Officer tetap harus diajukan kepada panitia pembiayaan untuk disetujui. Setelah disetujui, maka proses berikutnya sama seperti proses pembiayaan terhadap mitra baru. Terhadap pembiayaan yang menunggak antara 1-4 bulan, Account Officer harus memberikan surat pemberuathuan tunggakan. Apabila dalam jangka waktu tertentu mitra tetap tidak menyelesaikannya, maka Account Officer dapat mengalihkan mitra tersebut ke urusan/seksi legal dan remedial. Penanganan mitra pembiyaaan bermasalah oleh urusan/seksi legal dan remedial berbeda dari Account Officer. Oleh karena itu sebelum pembiayaannya dialihkan, mitra harus terlebih dahulu diberitahu hal tersebut. wewenang urusan/seksi legal adan remedial adalah menyelesaikan tunggakan mitra. Jika kolektibilitas pembiayaannya telah lancaar kembali, maka dapat diserahkan lagi kepada Account Officer.

\section{SIMPULAN DAN SARAN}

Penyelesaian sengketa ekonomi syariah di lembaga keuangan syariah bank maupun non bank dalam peraturan perundang-undangan bisa dilakukan melalui dua proses yaitu secara litigasi maupun non litigasi. Proses litigasi dilakukan melalui proses peradilan sedangkan non litigasi dilakukan melalui proses diluar peradilan. Dalam Undang-Undang Nomor 3 Tahun 2006 tentang Peradilan Agama dijelaskan bahwa Pengadilan Agama saaat ini diberi kewenangan untuk menangani sengketa ekonomi syari'ah.Penyelesaian sengketa melalui non litigasi dikenal dengan istilah Alternative Dispute Resolution (ADR) yang dalam perkembangannya di Indonesia lebih dikenal dengan Arbitrase, merupakan penyelesaian sengketa alternatif di luar pengadilan berdasarkan kesepakatan para pihak dengan mengesampingkan penyelesain sengketa secara litigasi di pengadilan. Penanganan sengketa di lembaga keuangan syariah kabupaten banyumas terkait dengan pembiayaan bermasalah lebih banyak dilakukan melalui non litigasi. Artinya untuk pembiayaan bermasalah lebih banyak diselesaikan secara internal lembaga melalui prosedur masing-masing lembaga yang hampir sama dalam penangannya. Perlu adanya pendirian lembaga arbitrase di kabupaten banyumas untuk menangani sengketa ekonomi sayariah di lembaga keuangan sebagai alternatif penyelesaian sengketa diluar pengadilan mengingat penyelesaian sengketa secara ADR yang lebih diminati oleh masyarakat.

\section{DAFTAR RUJUKAN}

Alamsyah, H. 2012. Perkembangan dan prospek perbankan syariah Indonesia: Tantangan dalam menyongsong MEA 2015. Makalah disampaikan pada Ceramah Ilmiah Ikatan Ahli Ekonomi Islam (IAEI). Milad ke-18 IAEI.(13 April 2012). 
Dokumen OJK. Lampiran Surat No. S-309/KO.033/2017 tanggal 31 Mei 2017

Hariyanto, Eri. Iqtishadia, Jurnal ekonomi dan Perbankan Syari'ah, Penyelesaian Sengketa Ekonomi Syari'ah di Indonesia,

Illy Yanti dan habriyanto, Penyelesaian Sengketa Ekonomi Syariah: Studi Kasus Sengketa Ekonomi Syariah di Lembaga Keuangan Syariah Kota Jambi Media Akademika, Vol. 27, No. 3, Juli 2012.

Itsabillah, Konsep-konsep Pemasaran. https://itsabillah.wordpress. com/tag/market-driven/

Manan, Abdul. 2014. Hukum Ekonomi Syariah Dalam Perspektif Kewenangan Peradilan Agama. Jakarta. Prenada Media Group.

Muhammad, Manajemen Pembiayaan Bank Syariah, (Yogyakarta: Akademi Manajemen Perusahaan YKPN, 2002 ),

Mujahidin, Ahmad. 2010. Prosedur Penyelesaian Sengketa Ekonomi Syariah Di Indonesia. Bogor. Ghalia Indonesia.

Muttaqien, Dadan. 2014. Materi Kuliah Mediasi Sengketa Ekonomi Syariah.

Nur jannah, Strategi Penyelamatan Pembiayaan Bermasalah Pada Pembiayaan Murabahah di Bank Syariah Mandiri Cabang Purwokerto, eljizya, jurnal ekonomi islam, vol. 4 no. 1 januari - juni 2016.

Rahmadi, Takdir. 2011. Mediasi Penyelesaian Sengketa Melalui Pendekatan Mufakat. Jakarta. Raja Grafindo.

Sholihin, Ahmad Ifham . 2010. Buku Pintar Ekonomi Syariah. Jakarta. Gramedia Pustaka Utama. 2010.

Soekanto, Soerjono. 1986. Pengantar Penelitian Hukum. Jakarta. Universitas Indonesia press.

Soemitra, Andri. 2012. Bank dan Lembaga Keuangan Syariah. Jakarta. Kencana.

Sudarsono, Kamus Hukum, Cetakan ke-3, Penerbit Rineka Cipta. Jakarta, 2002, hal. 433

Sutrisno, Hadi. 2001. Metodologi Research. Jilid 2. Yogyakarta. Andi Offset.

Syahrizal, Abbas. 2009. Mediasi: Dalam perspektif hukum syariah, hukum adat dan hukum nasional. Jakarta. Kencana. 